НОРМАТИВНАЯ И ЭКСТРЕМАЛЬНАЯ ПОВСЕДНЕВНОСТЬ СОВЕТСКОЙ ЭЛИТЫ 1945-1950 ГТ. (ПО МАТЕРИАЛАМ АРХИВОВ САНКТ-ПЕТЕРБУРГА)

\author{
(c) 2020 А.А. Амосова
}

Санкт-Петербургский государственный университет

Статья поступила в редакцию 17.02.2020

\begin{abstract}
В статье представлена характеристика источниковой базы исследования повседневной жизни советской элиты второй половины 1940-х годов Ленинграда и Ленинградской области с точки зрения истории эмоций. Сегодня в обществе существует запрос на углубленное осмысление позднего сталинизма и в том числе на изучение деятельности советской и партийной элиты указанного периода. Обращение исторической науки к исследованию эмоциональных стандартов повседневности (служебной и бытовой) позволяет по-новому осмыслить эпоху. Основной акцент сделан на анализе материалов, доступных в архивах Санкт-Петербурга (ЦГА СПб., ЦГАИПД СПб., ЦГА КФФД СПб.), а также музейных фондов.

Ключевые слова: история эмоций, повседневность, советская элита, поздний сталинизм, Ленгорсовет, Леноблсовет, «Ленинградское дело», архивы Санкт-Петербурга.
\end{abstract}

DOI: $10.37313 / 2658-4816-2020-2-1-59-63$

Исследование выполнено за счет гранта

Российского научного фонда (проект № 18-78-00060).

Предметная область исследования локализуется на изучении аспектов нормативной и экстремальной повседневности советских руководящих работников - председателей Ленинградского городского совета (П.С. Попков, П.Г. Лазутин, Андр. Алекс. Кузнецов) и Ленинградского областного совета (Н.В. Соловьев, И.С. Харитонов, И.Д. Дмитриев) второй половины 1940-х начала 1950-х годов.

Служебная и бытовая повседневность советской элиты Ленинграда и Ленинградской области второй половины 1940-х - начала 1950-х годов - тематика малоизученная. Это объясняется двумя факторами: 1) наличием в научных работах, посвященных сталинской эпохе, крена в сторону политической истории в ущерб социальной из-за сложности и противоречивости как внутри-, так и внешнеполитических реалий

Амосова Алиса Анатольевна, кандидат исторических наук, доцент кафедры музеологии Инстиmута истории СПбГУ. E-mail: a.amosova@spbu.ru того времени; 2) растянувшейся на десятилетия реабилитацией (правовой, партийной, моральной) жертв «Ленинградского дела», сделавшей изучение указанных персоналий, а также их государственной и политической деятельности негласно табуированным.

Поколение ленинградских руководящих кадров, прошедшее проверку на профессиональную пригодность в условиях войны и блокады, а затем и форсированного послевоенного восстановления народного хозяйства, пришло на руководящие посты в конце 1930-х годов, на волне репрессий «большого террора». «... команда Жданова во время войны вынесет на своих плечах все 872 дня блокады, а многие выходцы из нее будут работать на ключевых постах военной экономики СССР» ${ }^{1}$. В конце $1940-\mathrm{x}$ годов они сами оказались репрессированы по «Ленинградскому делу», в материалах Центрального Комитета именуемого также «Делом о ленинградских работниках»². 
Анализ нормативной повседневности предполагает выявление повторяющихся в личной и профессиональной жизни процессов, тяготеющих к стабильности, повторяемости, рутинности. Осмысление экстремальной повседневности основывается на изучении выходящих за рамки нормы событий, таких как служебные конфликты, фабрикация уголовного дела, аресты, следственные мероприятия, разлука с близкими и т.д.

В качестве ключевого подхода к исследованию была избрана эмоционология - научное направление, недостаточно востребованное в рамках отечественной исторической науки и в то же время весьма популярное за рубежом со второй половины $\mathrm{XX}$ в. Изучение эмоциональных стандартов позволяет индивидуализировать личностные черты представителей советской элиты.

С точки зрения истории эмоций понимать значение термина «emotion» следует расширительно, как метапонятия, переживаемого в различной форме отношения человека к человеку, к явлениям действительности и предметам ${ }^{3}$. Чувства формируются в процессе жизни человека, многие из них являются социокультурно обусловленными. Прежде всего речь идет о высших чувствах, таких как преданность «отцу народов», любовь к Родине, Ленинграду, товарищество в среде соратников, гордость за служебные достижения и др. Нередко низшие чувства приравнивают к эмоциям (страх, зависть и др.). Эмоции и чувства могут объяснять мотивы политических поступков, напрямую влиять на служебное поведение.

C конца XX в. в России активно развивается тематика, связанная с изучением повседневности (культурология повседневности). Однако научная традиция исследования повседневной жизни отдельными научными дисциплинами имеет более давнюю историю - со второй половины XIX в. Теоретическому осмыслению культуры повседневности посвящены работы М.B. Лукова ${ }^{4}$. В плане комплексного рассмотрения советской повседневности заслуживает внимания работа И.Б. Орлова ${ }^{5}$ За истекшие два десятилетия появилось значительное количество исследований, освещающих повседневную жизнь советских людей: работы Е.Ю. Зубковой, Н.Б. Лебиной, А.Н. Чистикова, В.Л. Пянкевича, Ф.К. Ярмолича ${ }^{6}$. Эти работы посвящены быту и досугу рядовых членов советского общества. Весомым вкладом в изучение эпохи, а также в осмысление бытовой и служебной повседневности советской элиты 1930-х - начала 1950х годов стала кандидатская диссертация Т.Н. Никаноровой ${ }^{7}$.

История эмоций, или эмоционология, считается изобретением XX в., хотя имеются тенденции «заглубления» научного дискурса к середине XIX в. или даже к более раннему периоду. За последние три с лишним десятилетия работы, посвященные истории эмоций, привели к созданию полноценного научного направления зарубежной исторической науки ${ }^{8}$. Однако осмыслению истории СССР с точки зрения эмоционологии посвящено очень незначительное количество работ 9 .

Источниковой базой исследования выступили материалы архивов Санкт-Петербурга. Наряду с ними были привлечены документы, отложившиеся в архивах Москвы (Государственный архив Российской Федерации, Российский государственный архив социально-политической истории, Российский государственный архив фонодокументов) и Республики Крым (Государственный архив Республики Крым) - в рамках анализа вех послевоенной биографии Н.В. Соловьева, занимавшего пост председателя Леноблисполкома в 1938-1946 гг.

Фонды Центрального государственного архива Санкт-Петербурга (далее - ЦГА СПб) хранят обширную коллекцию документов о деятельности местных органов государственной власти. Значимыми для исследования, в частности, стали фонды № 7384 «Санкт-Петербургский городской Совет народных депутатов» и № 7179 «Ленинградский областной Совет народных депутатов». В Центральном государственном архиве историко-политических документов 
Санкт-Петербурга (далее - ЦГАИПД СПб) отложились материалы, связанные с деятельностью партийных организаций разного уровня. В силу специфики изучаемого исторического периода, характеризовавшегося наличием двух типов органов власти - государственной и партийной, многие руководящие советские работники Ленинграда и Ленинградской области одновременно состояли в рядах ВКП(б), были членами бюро областного или городского комитетов партии. Большое значение для анализа служебной и бытовой повседневности номенклатурных работников имели материалы фондов: № 24 «Ленинградский областной комитет КПСС», № 25 «Ленинградский городской комитет КПСС».

Основными источниками исторического изучения эмоций принято считать так называемые эго-документы: письма, дневники, мемуары, интервью. Большинство ленинградских советских и партийных работников, чьи биографии оказались в предметном поле исследования, не имели возможности оставить воспоминания вследствие политических репрессий эпохи позднего сталинизма. В силу этих обстоятельств в качестве эго-документов были использованы автобиографии и листки по учету кадров из архивных личных дел председателей Ленгорисполкома ${ }^{10}$ и Леноблисполкома ${ }^{11}$, материалы неопубликованных публичных выступлений, сохранившихся в форме стенограмм ${ }^{12}$. Коллекция личных дел коммунистов была выделена в самостоятельныЙ фонд в ЦГАИПД СПб - фонд № 1728 «Коллекция личных дел коммунистов» ${ }^{13}$. Личные дела, помимо автобиографических записей и заполненных листков по учету кадров, содержат служебные характеристики, фотоизображения, способные дополнить представление об изучаемых представителях советской элиты. Однако при использовании указанных документов как источников изучения эмоциональной сферы повседневности, необходимо учитывать их официальный характер, демонстрирующий исследователю в большей степени ролевую норму, стандарт, а не реальный портрет политического деятеля.

Делопроизводственные документы, отложившиеся в вышеуказанных фондах ЦГА СПб и ЦГАИПД СПб (стенограммы заседаний ${ }^{14}$, пленумов, собраний, сессий советов за вторую половину 1940-х годов), имеют большое значение для изучения эмоционального фона служебной повседневности советской элиты: тексты стенограмм наряду с официальной лексикой содержат эмоционально окрашенные слова и выражения («с огромной радостью» ${ }^{15}$, «любимого вождя» $\left.{ }^{16} . ..\right)$. Однако на деловых мероприятиях руководители редко демонстрировали свои истинные чувства, заменяя их эмоциями политически обусловленными, соответствовавшими стандартному поведению советского руководящего работника (энтузиазм, упорство, неутомимость). Делопроизводственные документы 1945-1950 гг. источник вспомогательный, позволяющий дополнять общую канву исследования.

Исключение составляют материалы делопроизводственного характера, связанные с фабрикацией «Ленинградского дела» - например, стенограмма объединенного пленума Ленинградских обкома и горкома ВКП(б), состоявшегося 22 февраля 1949 г., посвященного рассмотрению ошибок, допущенных в Ленинградской партийной организации. Преобладающими эмоциями дискредитированных ленинградских руководителей стали: страх быть исключенным из партии, страх потерять должность и работу, апатия и трусость: «Любое наказание, какое будет, я готов выполнить и с честью буду драться за генеральную линию нашей большевистской сталинской партии» ${ }^{17}$. Из стенограммы становится очевидным наличие скрытых конфликтов в среде ленинградского актива, в частности, между первым секретарем Ленинградских обкома и горкома ВКП(б) П.С. Попковым и вторым секретарем Ленинградского горкома ВКП(б) Я.Ф. Капустиным ${ }^{18}$.

Фонды Центрального государственного архива кинофотофонодокументов Санкт- 
Петербурга (далее - ЦГА КФФД СПб) сохранили фотоизображения изучаемых персон за вторую половину 1940-х годов. К сожалению, сотрудники архива отказывают исследователям в ознакомлении с фонодокументами (записями устных выступлений представителей ленинградской элиты) указанного периода по причине ветхого состояния носителей (пленок). Работа с фонозаписями выступлений первого секретаря Ленинградских обкома и горкома ВКП(б) П.С. Попкова ${ }^{19}$ и председателя Ленгорисполкома П.Г. Лазутина ${ }^{20}$ стала возможной благодаря фондам московского РГАФ.

Подавляющее большинство охарактеризованных источников не являются в достаточной мере объективными для изучения повседневности советской элиты. Они демонстрируют стандарты служебного поведения, а также официальные, социокультурно обусловленные эмоции. Важнейшим источником, который позволяет пролить свет на бытовые аспекты повседневности, являются воспоминания родственников (материалы устной истории).

Целый комплекс воспоминаний детей жертв «Ленинградского дела» хранит Государственный музей политической истории России (далее - ГМПИР). Пронзительные и искренние, эти воспоминания в большинстве своем повествуют о времени репрессий, разлуке с близкими, ссылке ${ }^{21}$. Основные эмоции этих воспоминаний - печаль, страх, тоска. Дополнительно была проведена серия интервью с детьми руководящих работников местных органов государственной власти Ленинграда и области второй половины $1940-\mathrm{x}$ годов ${ }^{22}$. Материалы устной истории позволяют лучше понять эпоху, уяснить основные процессы, дополнить сухие факты эмоциональным содержанием. Вместе с тем не стоит абсолютизировать данные, полученные в рамках интервью с родственниками. Описанные события, равно как и личностные характеристики, нуждаются в проверке и уточнении в силу высокой субъективности данного вида источника.
Только комплекс материалов способен сформировать приближенное к истине представление о повседневности советской элиты Ленинграда и области второй половины 1940-х - начала 1950-х годов. Выявление и анализ указанной проблематики позволят разрушить стереотипы восприятия советской элиты исключительно в качестве региональных функционеров, персонифицировать их профессиональный вклад и индивидуализировать личностные черты.

\section{ПРИМЕЧАНИЯ}

${ }^{1}$ Волынец А. Жизнь замечательных людей: Жданов. М.: Молодая гвардия, 2013.

2 Дело о пересмотре дел и реабилитации лиц, осужденных по обвинению в контрреволюционных преступлениях // Российский государственный архив социально-политической истории (далее - РГАСПИ). Ф. 17. ОП. 171. Д. 439. Л. 105.

${ }^{3}$ Плампер Я. История эмоций. М.: Новое литературное обозрение, 2018. С. 18-22.

${ }^{4}$ См. напр.: Луков М.В. Культура повседневности. К истории вопроса // Библиотечное дело. М., 2010. № 7 (131). С. 6-13.

${ }^{5}$ Орлов И.Б. «Советская повседневность: исторический и социологический аспекты становления». М., 2010.

${ }^{6}$ См. напр.: Ярмолич Ф.К. Организация интеллектуального досуга жителей гор. Ленинграда в конце 1940-х-начале 1950-х гг. // Вестник ЛГУ им. А.С. Пушкина. № 2. Т. 4. История. СПб., 2012; Лебина Н.Б. Советская повседневность: нормы и аномалии // Лебина Н.Б. Энциклопедия банальностей: советская повседневность: контуры, символы, знаки. СПб., 2008; Зубкова Е.Ю. Послевоенное советское общество: политика и повседневность. 1945-1953 гг. М., 1999.

${ }^{7}$ Никонорова Т.Н. Документы Комиссии партийного контроля при ЦК ВКП(б) (1934-1952 гг.) как источник изучения экономической преступности в среде партийной номенклатуры. Дисс. .... канд. ист. наук. М., 2018.

${ }^{8}$ См. напр.: Плампер Я. История эмоций. М., 2018.

${ }^{9}$ Тематический выпуск журнала Slavic Review (Emotional turn? Feelings in Russian History and Culture / Ed. J. Plamper // Slavic Review. 2009. Vol. 68. № 2. Р. 229-334; Российская империя чувств: подходы к культурной истории эмоций / Под ред. Я. Плампера и др. М., 2010; Иванцов 
И.Г. Повседневность провинциального города 1920-1930-х годов, культурная история эмоций в документах органов партийно-государственного контроля ВКП(б) // Культурная жизнь Юга России. 2014. Т. 2. № 53. С. 68-72; Пянкевич В.Л. Люди жили слухами. Неформальное коммуникативное пространство блокадного Ленинграда. СПб.: Владимир Даль, 2014.

${ }^{10}$ См., напр.: Личное дело: Петр Сергеевич Попков // ЦГА СПб. Ф. 7384. ОП. 34. Д. 1783. Л. 4.

${ }^{11}$ См., напр.: Личное дело: Соловьев Николай Васильевич. // ЦГА СПб. Ф. 7179. Оп. 13. Д. 1128. Л. 4.

${ }^{12}$ См., напр.: Стенограмма предвыборного совещания избирателей Володарского района, посвященного встрече избирателей с кандидатом в депутаты Совета Национальностей Верховного Совета СССР Лазутиным П.Г. // ЦГАИПД СПб. Ф. 25. Оп. 5. Д. 1214. Л. 37-58.

${ }^{13}$ См., напр.: Личное дело: Лазутин Петр Георгиевич // ЦГАИПД СПб. Ф. 1721. ОП. 1. Д. 196640; Личное дело: Кузнецов Андрей Алексеевич // ЦГАИПД СПб. Ф. 25. ОП. 93. Д. 865; Личное дело: Харитонов Илья Степанович // ЦГАИПД СПб. Ф. 1728. Оп. 1. Д. 311298/4. Л. 25.

${ }^{14}$ См., напр.: Стенограмма предвыборного совещания избирателей Володарского района, посвященного встрече избирателей с кандидатом в депутаты Совета Национальностей Верховного Совета СССР Лазутиным П.Г. // ЦГАИПД СПб. Ф. 25. ОП. 5. Д. 1214.

15 Там же. Л. 13.

16 Там же. Л. 8.

${ }^{17}$ Стенограмма объединенного пленума Ленинградских обкома и горкома ВКП(б) 22 февраля 1949 г. // ЦГАИПД СПб. Ф. 24. ОП. 49. Д. 4-5.

${ }^{18}$ Там же.

${ }^{19}$ Попков П.С. Речь на похоронах А.А. Жданова // Российский государственный архив фонодокументов (далее - РГАФД). Ф.1. Оп. 1. Ед. хр. 107 (2).

${ }^{20}$ Лазутин П.Г. Выступление на митинге, посвященном 800-летию Москвы // РГАФД. Ф.1. ОП. 1. Ед хр. 81 (5).

${ }^{21}$ Воспоминания В.Ф. Михеева // ГМПИР; Воспоминания Г.Ф. Михеева // ГМПИР; Воспоминания Л.М. Сафонова // ГМПИР; Воспоминания Г.П. Талюш // ГМПИР.

${ }^{22}$ Интервью с Г.Ф. Михеевым и Т.А. Михеевой 10 октября 2018 г. // Из личного архива автора; Интервью с Э.И. Харитоновой 19 октября 2018 г. // Из личного архива автора; Интервью с Н.П. Сивцовой (Лазутиной) 27 октября 2018 г. // Из личного архива автора.

\title{
THE NORMATIVE AND EXTREME DAILY LIFE OF THE SOVIET ELITE IN 1945-1950 (BASED ON MATERIALS FROM THE ARCHIVES OF ST. PETERSBURG)
}

\author{
(C) 2020 A.A. Amosova
}

\section{St. Petersburg State University}

\begin{abstract}
The article contains the characteristics of the source base for the study of the daily life of the Soviet elite in the second half of the 1940s in Leningrad and the Leningrad Region through the prism of the history of emotions. Today, there is a demand in society for in-depth understanding of late Stalinism, including the study of the activities of the Soviet and party elite of this period. The appeal of historical science to the study of the emotional standards of everyday life (both working and domestic) allows a new understanding of the era. The author focuses mainly on the analysis of materials available in the archives of St. Petersburg (The Central State Archive of St. Petersburg, The Central State Archive of Historical-Political Documents of St. Petersburg, The Central State Archive of Cinema and Photo Documents of St. Petersburg), as well as museum collections.

Keywords: history of emotions, everyday life, Soviet elite, late Stalinism, Leningrad City Council, Leningrad Regional Council, the «Leningrad Affair», archives of Saint-Petersburg.

DOI: $10.37313 / 2658-4816-2020-2-1-59-63$
\end{abstract}

Alisa Amosova, Candidate of History, Associate Professor. Department of Museology of the Institute of History.E-mail: a.amosova@spbu.ru 